\title{
Investigation of Students' Attendance Patterns and Measures in Place to Curb the Menace in Secondary Njoro Sub-County, Kenya
}

\author{
Eliud Kipngeno Korir ${ }^{1}$, Bahati Charo Margaret ${ }^{2}$, Wesley Kipsang Bett ${ }^{3}$, \\ Dr. Ruth Thinguri ${ }^{4}$ \\ ${ }^{1,2,3}$ School of Education, Mount Kenya University P. O. Box, 342-01000, Thika, Kenya.
}

\begin{abstract}
Students' school attendance is still a major challenge in Kenya secondary levels of education. Therefore, this research analyzed student's school attendance and measures put in place to curb the problem in secondary schools in Njoro sub-county in Kenya. This study was set to look into: student's school attendance; causes of student school non-attendance and students performance in order to establish ways of mitigating this trend. Moreover, findings of this study were to assist the following individuals: students, teachers and the school administration such that it will assist students to know effects of school non-attendance; it will also assist teachers to be able to formulate ideas on how to reduce student's absenteeism.The study used descriptive survey design targeting all public secondary schools in Njoro sub-county. The target population for the study comprised of 169 male and 89 female teachers. There were more than 30 public secondary schools. Simple random sampling was used to select 8 schools and 156 teachers. Data was collected using questionnaires for teachers. Data collected was analyzed by descriptive statistics. Analyzed data was presented by use of frequency distribution tables. The researcher established that schools do not vary the ways of improving student's school attendance, since there is strong negative correlation between absenteeism and academic performance.
\end{abstract}

Keywords: Attendance Pattern, Absenteeism

\section{Introduction}

In Kenya, introduction of subsidized secondary education to all students in public secondary school was intended to improve student's school attendance. The launch of free day secondary education program was well received as it had much to be admired such as Kenyan government was to pay tuition fees for the parents while parents were to meet boarding cost and buy uniforms for their children. In addition, government had forewarned secondary schools head teachers from introducing illegal levies that may impede secondary schools enrolment. This shows that students attending day school is expected to pay for uniform only. In contrary, no school is abiding by that policy. The main objective of free day secondary education was to increase enrolment in secondary education. The table below shows the enrolment from the year 2002- 2010, presented in even years.

Table 1: School Enrollment: Secondary (\% gross) in Kenya

\begin{tabular}{|c|c|c|c|c|c|c|}
\hline & & Jan, 2002 & Jan, 2004 & Jan, 2006 & Jan 2008 & Jan, 2010 \\
\hline $\begin{array}{l}\text { increase } \\
\text { enrolment }\end{array}$ & in & 42.92 & 47.66 & 49.85 & 59.12 & 60.17 \\
\hline $\begin{array}{l}\text { Percentage } \\
\text { increase }\end{array}$ & & 66.03 & 73.32 & 76.69 & 90.95 & 92.57 \\
\hline
\end{tabular}

Source: World Bank (2010)

Table above indicate that there was ascending rate of enrolment to secondary education since the year 2002 to the year 2010. This can be accredited to the significant government policies especially theFSE policies instituted since 2002 in Kenya. Day schools have contributed highly to theattainment of these rates. Even though the increase in enrolment to the secondary schools, rate of school attendance is still wanting.

Table 2: Students School Attendance Pattern

\begin{tabular}{|llll|}
\hline Total school days & Mean & N & Std. Deviation \\
\hline 60.00 & 9.3463 & 363 & 12.23720 \\
Total & 9.3463 & 363 & 12.23720 \\
\hline
\end{tabular}

Source: Korir et.al 2014 
The table above shows that student's school absenteeism has the mean of 9.3463 days per term. Therefore, absenteeism is relatively high, thus free day secondary education policy has done less in retention of student's school attendance.

The organizational structures and culture of a school setting contributes to how students experience the system. School characteristics and culture can influence student absenteeism (Epstein \& Sheldon, 2002). Possibly organizational school structures endorse reward to particular peer groups while ignoring the others. If so, peer identity becomes relevant in schools as the values, attitudes and beliefs held within the peer groups affect those in the group to endorse or reject the mission of schools. Haris (1996) claims that peer groups are more powerful than parents in changing the values of an individual. In course of the study, the researcher intends to examine other factors that cause student school non-attendance in school environment. Moreover, students who struggled in school, failed credits, and had been kicked out of school were also found to be more likely to be absent (Nicholas, 2003).

\section{Statement of Problem}

The government of Kenya implemented Free Day secondary education after some success in free primary education with the main objective of this program to make secondary education accessible to all children graduating from primary education. However, government succeeded in enrolment but less has been done to retain these students in the schools. Thus, this study analyzed students' school attendance and measures put in place to absenteeism.

\subsection{Purpose of the Study}

Theresearchersinvestigatestudent's school attendance and measures put in place to reduce absenteeism in Njoro sub-county, Kenya.

\subsection{Objective of the Study}

Objectives guiding the study are:

i. To establish students school attendance patterns inNjoro sub-county, Kenya.

ii. To determine ways, schools use to control absenteeism in Njoro sub-county, Kenya.

\subsection{Significance of the Study}

The national goals of economic recovery and industrialization are jeopardized by students' poor academic performance in public secondary schools which may arise from absenteeism. The information provided by this research study will be important for the Ministry of Education and other stakeholders who have an interest in quality education. The public and the parents also have an interest in education having invested heavily in it. The society expects good returns for its investment in terms of good academic performance. Policy makers in education may tap from the knowledge derived from the research.

\section{Literature Review}

Studies by World Bank report (2004), on poverty in Kenya based on welfare monitoring survey, Children do not attend school for some reasons; non-affordability of education is 30 percent, early marriage account for 11.9 percent, school being boring is 11.8 percent and failure in exams is 10.4 percent, in rural areas. For the poor urban household, they are mostly affected by lack of affordability and it rated 34.2 percent, early marriage is 17.3 percent and account for 5.0 percent of all children who are out of school. From literature, it is clear that there are several contributors of school non-attendance which may vary, these include nonaffordability, early marriage, failure in exams and lack of interest in school. Correspondingly, empirical studies of high schools in Indiana in USA on relationship among yearly absence for failing students. Nicholas (2003) found that school absence is more frequent for students who are struggling academically. This shows that student with low academic grades attend school irregularly compared to those of high academic grades. These have rekindled the need to look into various causes of school non-attendance in Njoro District.

Studies, according to Lozt and Lee (1999), 'a great number of adolescent receive less supervision by their parent than in the past and contributes to unremitting school non-attendance.' When the parents fail in above-mentioned roles, students will be independent on deciding whether to attend school or not. Alternatively, Studies investigating family practices have suggested that, 'not all parent-involvement activities are associated with attendance,' according to (Lee, 1994). The contributing factors to chronic absenteeism involve parental and school-based responsibility.

\section{Research Methodology}

Researchersused quantitative research method, since projected data used in form of numerical. The study adopted ex-post facto research design, because researchers did not manipulate nor had control of 
independent variables since their manifestation has already occurred. Data was collected using one questionnaire for teachers and documentary analysis. A checklist was used to collect students' percentage scores in attendance and academic performance from eight secondary schools, used in this study. Descriptive and inferential statistics was used to analyze the data obtained, including frequency counts, mean, percentages. The researchers processed data and analyzed using descriptive statistics with the aid of Statistical Package for Social Science (SPSS Version 18). Analyzed data was presented in summary form using frequency distribution tables, and descriptive tables.

\subsection{School related causes of school non-attendance}

\section{ResearchResultsand Discussion}

Table 3:School related causes of school non-attendance

\begin{tabular}{|c|c|c|c|c|c|c|c|}
\hline & & & & 3 & 4 & & \\
\hline & $\mathrm{N}$ & 1 & 2 & & & Mean & Std. Deviation \\
\hline school characteristic and culture & 156 & 35 & 14 & 74 & 35 & 2.6889 & 1.06221 \\
\hline $\begin{array}{l}\text { influence students school } \\
\text { attendance }\end{array}$ & & $(22.2 \%)$ & $(8.9 \%)$ & $(46.7 \%)$ & $(22.2 \%)$ & & \\
\hline $\begin{array}{l}\text { students school absenteeism is } \\
\text { caused by incompetent of teachers }\end{array}$ & 156 & $94(60 \%)$ & $35(22.2 \%)$ & $7(4.4 \%)$ & $20(13.3 \%)$ & 1.7111 & 1.05792 \\
\hline $\begin{array}{l}\text { most students fail to attend school } \\
\text { because of the school being boring }\end{array}$ & 156 & $\begin{array}{c}94 \\
(60 \%)\end{array}$ & $\begin{array}{c}45 \\
(28.9 \%)\end{array}$ & $\begin{array}{c}17 \\
(11.1 \%)\end{array}$ & $\begin{array}{r}0 \\
(0.0 \%)\end{array}$ & 1.5111 & .69486 \\
\hline $\begin{array}{l}\text { most students fail to attend school } \\
\text { because they had failed in exams }\end{array}$ & 156 & $\begin{array}{c}56 \\
(35.5 \%) \\
\end{array}$ & $\begin{array}{c}69 \\
(44.4 \%) \\
\end{array}$ & $\begin{array}{c}24 \\
(15.6 \%)\end{array}$ & $\begin{array}{r}7 \\
(4.4 \%)\end{array}$ & 1.8889 & .83182 \\
\hline Valid N (listwise) & 45 & & & & & & \\
\hline
\end{tabular}

Introduction of free tuition secondary education led to increase in the number of students that enroll in secondary education. In addition, it has led to decrease in student's absenteeism. The mean score 3.435 of the respondents that acknowledge free tuition secondary education has increased students school attendance it is represented by 82.6 percent of teachers in Njoro District. Even though, introduction of free tuition secondary education increased students school attendance in the same measure it has led to relative low performance especially in secondary schools. According to Ogola (2010) shortage of teaching and learning materials, facilities have negative impact on the quality of teaching and learning. Therefore, improvement of students school attendance without increasing learning resources, facilities and teaching workforce, does not necessarily improve student's academic performance.

Mobility of students from one class to another without considering their academic performance is common in Njoro District secondary schools and $(50 \%)$ of teachers reported that it is practiced in their schools, this translate that half of schools in Njoro district allow students to proceed to the next class without considering academic performance. According to Rozumah (2003), automatic movement from one class to the next, provide some of the student's opportunity not attend school daily. From the study, it shows that (47.7\%) of the teachers admit that automatic promotion to the next class encourages absenteeism, on the other hand (52.3\%) of the teachers in Njoro District secondary school believe that automatic promote has no significance on absenteeism. Thus, as government established a policy that avoid repetition of students in the same way, it has also to put in place policy that indicates minimum number of days that student must attain in order to be promoted to the next class.

\subsection{Causes of Absenteeism}

The next subsection looks into the main causes of student's school absenteeism, and it is divided into two main section home-related causes and school related causes. In addition, these sections were presented as nine items to teachers in Table 3.

\subsubsection{School related causes of student's absenteeism}

Table 3 shows respondents distribution on percentage, mean and standard deviation for school related causes of absenteeism. Based on the study, item 'school characteristics and culture influence students school attendance' has highest mean score of 2.6889 and standard deviation of 1.06221. Only 35 respondents, which are 22.2 percent strongly, disagree with this item whereas 14 respondents, which are 8.9 percent, disagree with this item. Seventy-three respondents, which are 46.7 percent, agreed with this item. Thirty-five respondents, which are 22.2 percent highly, agreed with these items. According Epstein and Sheldon (2002), 'organizational school structures endorse reward particular peer groups while ignoring the others.' If so, peer identity becomes relevant in schools as the values, attitudes and beliefs held within the peer groups predispose those in the group to endorse or reject the mission of schools. Thus, studies by Epstein and Sheldon are in agreement with this study, whereby above-mentioned item is the main influence of school attendance. 
The fourth highest mean score is 'most students fail to attend school because of the school being boring', withthe mean of 1.5111 and standard deviation 0.69486. A number of 38 respondents, which are 60 percent strongly, disagreed with this item, while 19 respondents, which are 28.9 percent, did not agree with this item. Seven respondents, which are 11.1 percent, agreed with this item. None strongly agreed with these items. This shows that in spite of this item is the least cause of absenteeism, but it contributes to some extent.

\subsubsection{Home related causes of school non-attendance}

Table 4:Home related causes of school non-attendance

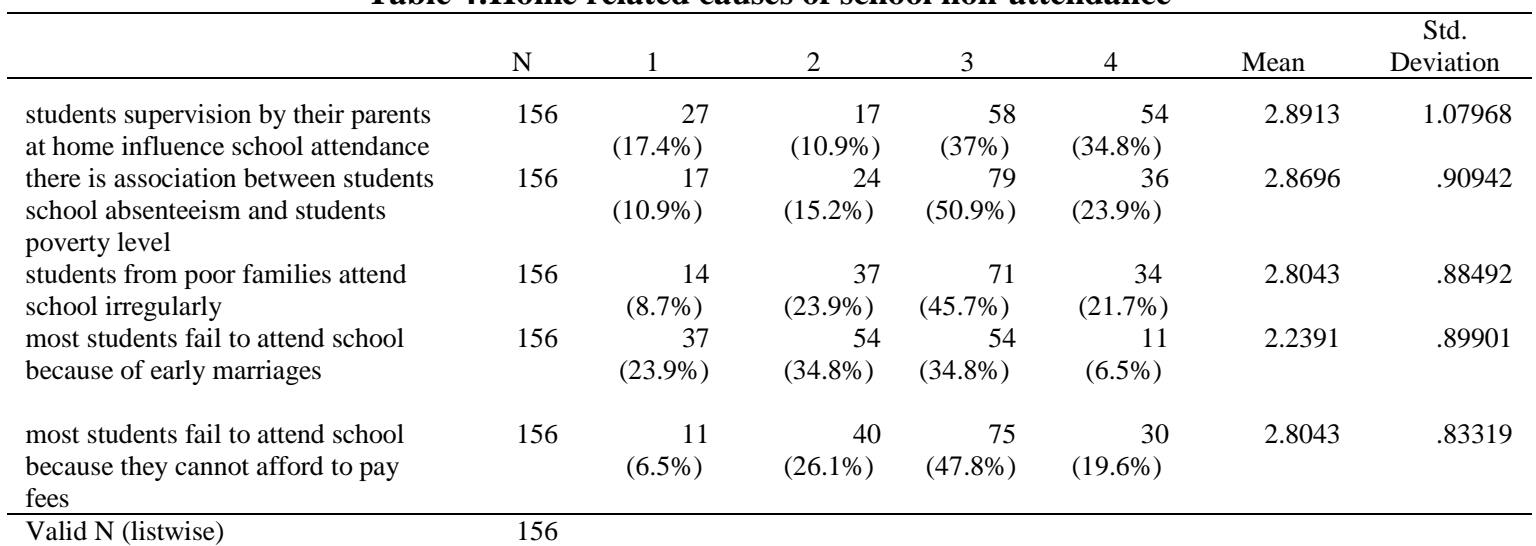

Table 4shows respondent distribution on: percentage, mean and standard deviation for home-related causes of student's school non-attendance. From the table there are several home related causes of absenteeism among students, based on this study 5 items were presented to teachers, it clear from the table 9 that students supervision by their parents at home influence school attendance. Study found that (74\%) of the teachers in Njoro district, believe that students supervision by their parents at home contribute much to school attendance. According to Lotz and Lee (1999), adolescent receive less supervision by their parents compared to the past, this is one of the contributors of increase in students absenteeism. On the other hand, poverty has been perceived to be major cause absenteeism. Nicholas (2003) found that students from low-income families had a greater failure rate and school absence become more frequent, especially for students who struggle academically. In Table 12 it shows that poverty level affect negatively students school attendance, such that with increase in poverty level it leads to increase in absenteeism, in addition 69.5 percent of the respondents agreed that most students failed to attend school because they cannot afford to pay fees.

\subsection{Learning and academic performance}

An analysis on learning and academic performance was presented as six items in Table 5. The information from the item 'low students school attendance is unfavorable to learning and academic performance' has the higher mean score of 3.9778 and standard deviation of 0.4989 . Respondents who strongly disagreed are three, which are represented by 2.2 percent; on the other hand, respondents that disagreed are 21 , which are represented by 13.3 percent. The total number of respondents that agreed with the item is 131 , which are 84.5 percent. This is an indication that school attendance is most important to learning and academic performance. Data collected on relationship between time spent by the student and academic performance, under the item 'the study time spent by students is directly proportion to academic performance,' has the mean score of 3.200 and standard deviation of 0.72164 . A number of respondents that disagreed are 21 which are represented by 13.3 percent, on contrary 135 respondents which are 86.7 percent agreed with the item. Therefore, the time spent in the study by the student is positively correlated with the academic performance.

The finding of this study can be synchronized with the fact that, even if students school attendance is considered as a key to academic performance, quality of instruction need to be looked into. The information from the table shows that the item 'quality of instruction across teachers determine performance of the students,' has the mean score of 2.9778 which is relatively high and standard deviation of 0.8115 . The number of respondents that disagreed with the item is 38 , which are 24.4 percent, whatsoever respondents that agreed the item are 118 , which are 75.0 percent. This show that as student's school attendance is valued as a way of improving academic performance, moreover the quality of instruction must be consideredtoo. 


\subsection{Effects of School Attendance on Academic Performance}

Table 5: Effects of School Attendance on Academic Performance

\begin{tabular}{|c|c|c|c|c|c|c|c|}
\hline & $\mathrm{N}$ & 1 & 2 & 3 & 4 & Mean & $\begin{array}{c}\text { Std. } \\
\text { Deviation }\end{array}$ \\
\hline $\begin{array}{l}\text { Students absenteeism in a class affect } \\
\text { achievement of students that attend } \\
\text { school regularly through disruption of } \\
\text { existing groups }\end{array}$ & 156 & $\begin{array}{r}7 \\
(4.4 \%)^{7}\end{array}$ & $\begin{array}{r}24 \\
(15.6 \%)\end{array}$ & $\begin{array}{r}90 \\
(57.8 \%)\end{array}$ & $\begin{array}{r}35 \\
(22.2 \%)\end{array}$ & 2.9778 & .75344 \\
\hline $\begin{array}{l}\text { Students who study on their own do } \\
\text { well as those who attend class if } \\
\text { teachers explain only the content in the } \\
\text { text book }\end{array}$ & 156 & $\begin{array}{r}45 \\
(28.9 \%)\end{array}$ & $\begin{array}{r}66 \\
(42.2 \%)\end{array}$ & $\begin{array}{r}31 \\
(20 \%)\end{array}$ & $\begin{array}{r}14 \\
(8.9 \%)\end{array}$ & 2.0889 & .92496 \\
\hline $\begin{array}{l}\text { Formal study is much more important } \\
\text { than self study }\end{array}$ & 156 & $\begin{array}{c}14 \\
(8.9 \%)\end{array}$ & $\begin{array}{r}41 \\
(26.7 \%)\end{array}$ & $\begin{array}{r}66 \\
(42.2 \%)\end{array}$ & $\begin{array}{r}35 \\
(22.2 \%)\end{array}$ & 2.7778 & .90174 \\
\hline $\begin{array}{l}\text { Mandatory students school attendance } \\
\text { boost an average students' } \\
\text { performance }\end{array}$ & 156 & $\begin{array}{r}10 \\
(6.7 \%)\end{array}$ & $(4.4 \%)$ & $\begin{array}{r}73 \\
(46.7 \%)\end{array}$ & $\begin{array}{r}66 \\
(42.2 \%)\end{array}$ & 4.1333 & 6.13337 \\
\hline $\begin{array}{l}\text { Some students attend school regularly } \\
\text { and still struggle just as those who } \\
\text { regularly miss classes }\end{array}$ & 156 & $\begin{array}{r}17 \\
(11.1 \%)\end{array}$ & $\begin{array}{r}52 \\
(33.3 \%)\end{array}$ & $\begin{array}{r}59 \\
(37.8 \%)\end{array}$ & $\begin{array}{r}28 \\
(17.8 \%)\end{array}$ & 3.0667 & 3.02565 \\
\hline $\begin{array}{l}\text { Holiday tuition for secondary school } \\
\text { students does not add any value to } \\
\text { student's academic performance }\end{array}$ & 156 & $\begin{array}{c}100 \\
(64.4 \%)\end{array}$ & $\begin{array}{r}35 \\
(22.2 \%)\end{array}$ & $\begin{array}{r}7 \\
(4.4 \%)^{7}\end{array}$ & $\begin{array}{r}14 \\
(8.9 \%)\end{array}$ & 1.5778 & .94120 \\
\hline $\begin{array}{l}\text { Students innate abilities influence } \\
\text { performance more than students } \\
\text { school attendance }\end{array}$ & 156 & $\begin{array}{r}17 \\
(11.1 \%)\end{array}$ & $\begin{array}{r}56 \\
(35.6 \%)\end{array}$ & $\begin{array}{r}62 \\
(40 \%)\end{array}$ & $\begin{array}{r}21 \\
(13.3 \%)\end{array}$ & 2.5556 & .86748 \\
\hline $\begin{array}{l}\text { Low students school attendance is } \\
\text { unfavorable to learning and academic } \\
\text { performance }\end{array}$ & 156 & $(2.2 \%)^{3}$ & $\begin{array}{r}21 \\
(13.3 \%)\end{array}$ & $\begin{array}{r}56 \\
(35.6 \%)\end{array}$ & $\begin{array}{r}76 \\
(48.9 \%)\end{array}$ & 3.9778 & 4.49489 \\
\hline $\begin{array}{l}\text { The study time spent by students is } \\
\text { directly proportional to academic } \\
\text { performance }\end{array}$ & 156 & $(2.2 \%)^{3}$ & $\begin{array}{r}17 \\
(11.1 \%)\end{array}$ & $\begin{array}{r}80 \\
(51.1 \%)\end{array}$ & $\begin{array}{r}56 \\
(35.6 \%)\end{array}$ & 3.2000 & .72614 \\
\hline $\begin{array}{l}\text { Quality of instruction across teachers } \\
\text { determine the academic performance } \\
\text { of students }\end{array}$ & 156 & $\begin{array}{r}7 \\
(4.4 \%)^{7}\end{array}$ & $\begin{array}{r}31 \\
(20 \%)\end{array}$ & $\begin{array}{r}76 \\
(48.9 \%)\end{array}$ & $\begin{array}{r}41 \\
(26.1 \%)\end{array}$ & 2.9778 & .81153 \\
\hline $\begin{array}{l}\text { Low quality of instruction by teachers } \\
\text { causes poor academic performance }\end{array}$ & 156 & $\begin{array}{r}14 \\
(8.9 \%)\end{array}$ & $\begin{array}{r}45 \\
(28.9 \%)\end{array}$ & $\begin{array}{r}56 \\
(35.6 \%)\end{array}$ & $\begin{array}{r}41 \\
(26.7 \%)\end{array}$ & 2.8000 & .94388 \\
\hline $\begin{array}{l}\text { Students who attend remedial teaching } \\
\text { more often perform better in exams }\end{array}$ & 156 & $\begin{array}{r}7 \\
(4.4 \%)\end{array}$ & $\begin{array}{r}24 \\
(15.6 \%)\end{array}$ & $\begin{array}{r}69 \\
(44.4 \%)\end{array}$ & $\begin{array}{r}52 \\
(33.3 \%)\end{array}$ & 3.7556 & .53349 \\
\hline $\begin{array}{l}\text { Implementation of policies on } \\
\text { improvement of students academic } \\
\text { performance }\end{array}$ & & & & & & & \\
\hline $\begin{array}{l}\text { Students sign-in and sign-out policies } \\
\text { produces significant influence on } \\
\text { students achievements }\end{array}$ & 156 & $\begin{array}{r}24 \\
(15.6 \%)\end{array}$ & $\begin{array}{r}38 \\
(24.4 \%)\end{array}$ & $\begin{array}{r}76 \\
(48.9 \%)\end{array}$ & $\begin{array}{r}17 \\
(11.1 \%)\end{array}$ & 2.5556 & .89330 \\
\hline Valid N (listwise) & 156 & & & & & & \\
\hline
\end{tabular}

The table 5 shows respondents distribution based on percentage mean and standard deviation. Result from the item 'students with regular attendance score high in continuous assessment test,' has the higher mean score of 3.2889 and standard deviation of 0.96818 . Only 17 respondents, which are 11.1 percent, strongly disagree with the item. Three respondents, which are 2.2 percent, disagreed. Whereas, 52 respondents, which are 33.3 percent, agreed with item and 83 respondents which are 53.3 percent strongly agreed with the item. This shows student's school attendance improve academic performance. Moreover, the item 'student's absenteeism in a class affect achievement of the students that attend school regularly through disruption of existing groups,' has the mean score of 2.9778 and standard deviation of 0.75344 . A number of seven respondents, which are 4.4 percent strongly, disagreed, whereas 24 respondents, which are 15.6 percent, did not agree with the item. In addition, 90 respondents, which are 57.8 percent, agreed with item and 35 respondents strongly agreed with the item. This shows that students who fail to attend school disrupt discussion groups, which may eventually affect overall achievements of students who attend school regularly.

From the table the item 'students, who study on their own do well as those attend class if teachers explain only the content in the assignment,' has the mean score of 2.0889 and standard deviation of 0.9249 . Number 37 respondents, which represent 28.7 percent strongly, disagreed with item, whereas 66 respondents, which are 42.2 percent, disagreed with the item. The total of respondents that agreed with the item is 45 . This shows that students who study on their own without teacher assistance do not performance better as students that do attend school and this finding seem to disagreed with the findings of Brown et al (1991), established that students who study on their own do well as those attend class if the teacher explain the content in the assignment. 
Data collected showed that mandatory school attendance boost an average student's performance. From the table this item has mean score of 4.1333 and standard deviation of 0.613337 . Respondents represented by 11.1 percent disagreed with this item, whereas 88.9 percent agreed that mandatory school attendance boost academic performance of the students. Above study is in harmony with the study of Wright (1997) on making school attendance obligatory in order to improve performance.

The respondents were asked if holiday tuition for secondary schools do not add any value to student's academic performance, majority of the respondents did not agreed. One-hundred and thirty five respondents, which are 86.6 percent, contrary to those 21 respondents, which are 13.3 percent, agreed with item, and this has the lowest mean score of 1.55778 and standard deviation of 0.91120 . This shows that holiday tuition is an important in improving academic performance. Moreover, the item 'students who attend remedial teaching more often perform better in exams,' has the mean score of 3.75566 and standard deviation of 0.53349 . A number of 31 respondents, which represent 20.0 percent, disagreed with the item whereas, 125 respondents, which are 80 percent, agreed with the item. This is an indication that remedial teaching improves academic performance.

\subsection{Ways of improving academic performance}

The study was to establish the ways of improving academic performance in Njoro District secondary schools, in table 5. Out 156 respondents on students sign-in and sign-out policies, 94 (60\%) agreed that the policy improved the performance through absenteeism check among students, whereas 62 (40\%) individuals did not agree with item. This shows continuous check of student's school attendance improves academic performance.

The study also established that majority of teachers through the item 'students who perform poorly in average mean grade are retained in school for remedial teaching when the school closes for holiday.' 31 Respondents agreed the above item is practiced in their schools, which are 19.6 percent. On the other hand, 126 respondents reported that it is does not exist in their respective schools. This shows that remedial teaching for students with low academic performance over the holiday does not exist in most schools in Njoro District. In addition, 134 respondents agreed that the above practice is crucial in improving academic performance, representing 85.9 percent of the respondents, whereas 22 respondents, which are 14.1 percent, disagreed that remedial teaching for weak students over the holiday does not necessarily improve performance. This shows that student's school attendance for remedial teaching relatively improves academic performance.

Table 6: Ways of improving academic performance

\begin{tabular}{|c|c|c|c|c|c|}
\hline & $\mathrm{N}$ & no & Yes & Mean & Std. Deviation \\
\hline $\begin{array}{l}\text { make home visit of chronically } \\
\text { absent students }\end{array}$ & 156 & 145 & 11 & 1.0705 & .25683 \\
\hline $\begin{array}{l}\text { rewards students for improved } \\
\text { attendance }\end{array}$ & 156 & 114 & 42 & 1.2692 & .44499 \\
\hline $\begin{array}{l}\text { establish a contact person at } \\
\text { school for parents to work with }\end{array}$ & 156 & 128 & 28 & 1.1795 & .38500 \\
\hline $\begin{array}{l}\text { conduct workshops for the } \\
\text { parents about student school } \\
\text { attendance }\end{array}$ & 156 & 156 & 0 & 1.0000 & .00000 \\
\hline $\begin{array}{l}\text { refer chronically absent students } \\
\text { to counselor }\end{array}$ & 156 & 156 & 0 & 1.0000 & .00000 \\
\hline call home when student are absent & 156 & 139 & 17 & 1.1090 & .31261 \\
\hline Valid N (list wise) & 156 & & & & \\
\hline
\end{tabular}

Table 6 shows the number of schools that reported using each practice to help improve student's attendance. The item 'rewards students for improved attendance' scored the mean of 1.2692 with standard deviation of 0.4449 . This relatively higher mean score compared to the rest, even though it is below average. However, two items; 'conduct workshops for parents about attendance' and 'refer chronically absent students to counselors' have the mean score of 1.000 . This shows that the practice does not exist in the selected schools.

Table 7: Family and community involvement activities

\begin{tabular}{|c|c|c|c|c|c|c|}
\hline & $\mathrm{N}$ & 1 & 2 & 3 & Mean & Std. Deviation \\
\hline $\begin{array}{l}\text { make home visits of } \\
\text { chronically absent } \\
\text { students }\end{array}$ & 156 & 0 & $\begin{array}{r}135 \\
(86.5 \%)\end{array}$ & $\begin{array}{r}21 \\
(13.5 \%)\end{array}$ & 2.1346 & .34241 \\
\hline $\begin{array}{l}\text { rewards students for } \\
\text { improved attendance }\end{array}$ & 156 & 0 & $\begin{array}{r}115 \\
(73.7 \%)\end{array}$ & $\begin{array}{r}41 \\
(26.3 \%)\end{array}$ & 2.2628 & .44158 \\
\hline $\begin{array}{l}\text { establish a contact person } \\
\text { at school for parents to } \\
\text { work with }\end{array}$ & 156 & 0 & $\begin{array}{r}124 \\
(79.5 \%)\end{array}$ & $\begin{array}{r}32 \\
(20.5 \%)\end{array}$ & 2.2051 & .40510 \\
\hline conduct workshops for & 156 & 0 & 151 & 5 & 2.0321 & .17670 \\
\hline
\end{tabular}


Investigation of Students' Attendance Patterns and Measures in Place to Curb the Menace ....

\begin{tabular}{lccrrrr}
$\begin{array}{l}\text { families about student } \\
\text { school attendance }\end{array}$ & 156 & 0 & $(96.8 \%)$ & $(3.2 \%)$ & & \\
$\begin{array}{l}\text { refer chronically absent } \\
\text { student to counselor } \\
\text { call home when student } \\
\text { are absent }\end{array}$ & 156 & 0 & $\begin{array}{r}148.8 \%) \\
133\end{array}$ & $\begin{array}{r}(5.1 \%) \\
23\end{array}$ & 2.0513 & .22128 \\
\hline Valid N (list-wise) & 156 & & $(85.3 \%)$ & $(14.7 \%)$ & & .35568 \\
\hline
\end{tabular}

Respondents were asked to account whether the following practices in their schools conducted various family and community involvement activities and the extent to which these practices are implemented. Above named practices was reported to been beneficial in improving attendance. Generally, most of the respondents viewed each practice as generally useful as in table 7 . The perceived effectiveness of practice ranging from a mean of 2.0513 to 2.268 , rewarding students for improved performance $(\mathrm{M}=2.2628, \mathrm{SD}=0.34241)$, having person at school for parents to contact $(\mathrm{M}=2.2051, \mathrm{SD}=0,4051)$. Whereas, calling home when students are absent $(\mathrm{M}=2.1474, \mathrm{SD}=0.35568)$, making home visits $(\mathrm{M}=2.1346, \mathrm{SD}=0.34241)$, referring chronically absent students to the counselor $(\mathrm{M}=2.0513, \mathrm{SD}=0.22128)$, and conducting workshops for the parents about students school attendance $(\mathrm{M}=2.0321, \mathrm{SD}=0.1761)$ as less effective for improving students school attendance, though still helpful.

\section{Conclusion}

It was established from the study that student's absenteeism in Njoro secondary school it is real, and it is one of the element that causes poor performance, as in the study by Korir, Charo, Ogochi and Thinguri (2014). Therefore, as school intends to improve academic performance; schools in Njoro sub-county should explore various ways of improving student's school attendance. These practices include: make home visits of chronically absent students; rewards students for improved school attendance; establish a contact person at school for parents to work with; conduct workshops for families about students school attendance; refer chronically absent student to a counselor; call home when student is absent from the school.

\section{References}

[1]. Epstein, J. L., \& Sheldon, S. B. (2002). Present and accounted for: Improving student attendance through family and community involvement. Journal of Educational Research, 95, 308-318.High School Graduation Exam.”Preventing School Failure, 47(3): 112120

[2]. Korir, E. K., Charo, M. B., Ogochi, G. \&Thinguri, R. (2014). Student school Attendance and Academic Performance in Njoro District, Kenya: Relational Analysis. Vol. 2 | No. 5 May | 2014 ISSN 2347-8225

[3]. Lotz, R. \& Lee, L. (1999).Sociability, school experience and delinquency. Youth \& Society 31(3): Pp 199-224. Research in Economic Education, 32(2): 99-109.

[4]. Nicholas, J. D. (2003) "Prediction Indicators for Students Failing the State of Indiana

[5]. Ogola, F. O. (2010). Free Education in Kenyas Public Primary schools; Addressing challenges. Retrieved on 21/08/2014. From http//www.ossrea.net

[6]. Rozumah, B. \&Rumaya, J. (2005). Predictors of conduct problems among school going adolescents in West Malaysia. Malaysian Journal of Social Policy and Society, 2, 92-105.

[7]. World Bank. (2004). Strengthening the Foundation of Education and Training in Kenya: Opportunities and challenges in primary and General Secondary Education.World Bank: Washington DC. 